\title{
STRUCTURE OF HOUSEHOLD EXPENDITURES IN SLOVAKIA AND RELATIONS BETWEEN ITS CATEGORIES
}

\author{
Zuzana LAZÍKOVÁ \\ Slovak University of Agriculture in Nitra, Slovak Republic
}

\begin{abstract}
Household income is one of the basic indicators of the living standard of population in countries or regions. The income indicator is inextricably linked to the household expenditure indicator, whose structure also indicates the living standards of households. The development of income and expenditures of Slovak households has been affected by many events over the last decades (fulfilment of the Maastricht criteria, accession of the Slovak Republic to the EU, adoption of the euro currency, economic crisis). The category of gross cash expenditures, net cash expenditures or consumption expenditures may be used to assess household expenditures. Based on the classification by individual consumption by purpose (COICOP), the expenditures are divided into 12 basic categories. The development of individual categories of expenditures, however, should be analysed separately as there is no long-term balanced relationship between them.
\end{abstract}

Keywords: expenditures, categories, long-term balanced relationship

Income and expenditures of inhabitants can be observed by using two main methods. First one is looking at the final consumption of households within the system of national accounts and the second one is based on observing income and expenditures at the micro level based on the data from family accounts. The first method is based on analysing data of all inhabitants. The second method uses incomes and expenditures of representative sample of households, so called family accounts (Kaščáková and Nedelová, 2008). In the statistics of family accounts, the data for consumption expenditures (goods and services) and non-consumption (other) expenditures are collected (Vojtková and Labudová, 2010).

The current structure of the consumption expenditures of majority of Slovak households is the result of economic factors, in particular, the level of their income and the price changes of goods and services. However, the consumption of our households is also affected by the financial and economic crisis, while individual households deal with the impacts of crises differently (Vidová, 2015). Experience shows that the total consumption depends on the size of the disposable income and the level of the interest rate. The higher the interest rate, the lower the inclination to consumption, i.e. that consumption is a declining function of the real interest rate. At the same time, with the growth of income, consumption also increases, which means that consumption is a function of disposable income. Consumption includes durable goods (household equipment, cars), nondurable goods (food, clothing, energy) and services (housing, health care, education, recreation) (Lisý et al., 2011). In addition to the economic indicators, the development of structure and level of consumption is also influenced by many social and geographical factors, such as the structure of society by age and education, rate of price regulation, degree of economic development of the country, consumer traditions, etc. (Kollárová and Vladová, 2009). In the structure of consumption, the so-called Engel's law is valid: the more money someone has, the smaller portion of expenditures is used for the necessary living needs. In practice it can be seen for example by decreased share of expenditures spent on food and increased share used on health care, recreation, culture, etc. (Pauhofová and Páleník, 2012). High share of consumption in relation to income leads to low investments and slowdown of economic growth (Lisý et al., 2011).

Generally, expenditures represent outflow of money from households (Meyer and Sullivan, 2003), by other words, household expenditures represent all cash used to cover the needs of household members. In the developed countries, household expenditures spent on the purchase of consumption goods and services account for two thirds of the total spending (Lisý et al., 2011). The largest debit items of households consist of food, housing, water, electricity, gas and other fuels and transport (Frendáková, 2010).

The Statistical Office of the SR (2017) lists three groups of expenditures. Gross cash expenditures include consumption expenditures and other gross expenditures, i.e. other expenditures including income tax and compulsory personal insurance. Net cash expenditures include consumption and other net expenditures, i.e. other expenditures excluding income tax and compulsory personal insurance. The term other expenditures refers to expenditures for various payments (property tax and 
other, other gross expenditures also income tax and compulsory personal insurance), cash donations outside the household, instalment loans, purchase of shares and bonds, including short-term expenditures on private management (Statistical Office of the SR, 2017). The third group consists of consumption expenditures, which represent the amount of expenditures for goods and services.

The Statistical Office of the Slovak Republic, as well as the European Statistical Office EUROSTAT, classify household expenditures according to their purpose into 12 categories, referred to as COICOP (Classification of Individual Consumption by Purposes).

\section{Material and methods}

This article focuses on the structure of money expenditures divided by COICOP (Classification of Individual Consumption by Purpose) into 12 categories and the existence of a longterm balanced relationship between categories through a correlation matrix and cointegration tests.

The Statistical Office of the Slovak Republic uses the classification of the surveyed items within the family accounts statistics COICOP. Household expenditures are broken down by the purpose, which means according to the purpose, for which the money is spent or what component of the standard of living the goods and services satisfy. From 1997 to 2014, the COICOP-HBS classification was used; the COICOP-5 classification has been used since 2015 (Statistical Office of the SR, 2017). Based on the COICOP classification and in accordance with the Eurostat methodology, expenditures are broken down into 12 categories: food and non-alcoholic beverages; alcoholic beverages and tobacco; clothing and footwear; housing, water, electricity, gas and other fuels; furnishing, household equipment and routine household maintenance; health; transport; mail and telecommunications; recreation and culture; education; hotels, cafés and restaurants; miscellaneous goods and services (Statistical Office of the SR, 2017).

In order to identify the long-term balanced relationship between the expenditure categories, we used the EngleGranger test, which consists of several steps. First, the stationarity of the selected pair of expenditures was tested, followed by cointegration regression, while the residuals were again subjected to a stationary test. For stationary testing, the Dickey-Fuller test was used, which means unit root test, where the zero hypothesis assumes that the time series has a unit root and, therefore, it assumes nonstationarity. The time series $\mathrm{Zt}=\beta 0+\rho \mathrm{Zt}^{-1}+\varepsilon \mathrm{t}$ is stationary when the condition $|\rho|<1$ is fulfilled; if $\beta=0$ and $\rho=1$, then the time series is non-stationary (Dickey and Fuller, 1979).

\section{Results and discussion}

\section{Expenditures and the Expenditures' Structure of Households}

Generally, expenditures represent a cash outflow from households (Meyer and Sullivan, 2003). In developed countries, household expenditures spent on consumption goods and services accounts for two-thirds of total spending (Lisý et al., 2011). The largest debit items of household consist of food, housing, water, electricity, gas and other fuels and transport (Frendáková, 2010). These opinions are also confirmed by the Table 1, which shows the development of net cash household expenditures in Slovakia between 2004 and 2015.

However, this trend is presented not only in Slovakia, but also in the EU-28, as it is shown in Figure 1, where precisely these three selected categories represent the largest items of household expenditures.

There are, however, great differences between countries. In majority of the EU countries, expenditures on housing represent the largest share on the total expenditures, while the budgets of the new Member States are also burdened by the expenditures on food and non-alcoholic beverages (Dudek and Koszela, 2013), which proves the claim that economically less developed countries have higher expenditures on food and non-alcoholic beverages (Ševela, 2004). Food and non-alcoholic beverages represent the lowest expenditures in the UK (only $8.4 \%$ of the total expenditures), Luxembourg (9.4\%) and Ireland (9.5\%). On the contrary, food and non-alcoholic beverages in Romania (29.4\%), Lithuania (23.4\%) and Estonia (20.7\%) account for the highest share on the total expenditures (Eurostat, 2016). The highest housing costs out of the total expenditures are in Denmark (29.7\%) and Finland (28.2\%), and the lowest in Malta (10.1\%) and Lithuania (15.8\%). Within the total expenditures, the transportation costs account for $7 \%$ to $16 \%$, with the lowest costs in Slovakia, Spain and the Czech Republic, and the highest costs in Slovenia, Luxembourg and Bulgaria (Eurostat, 2016). The

Table 1 Total net cash expenditures in euros per person per month and selected expenditures from the total expenditures in \% between 2004 and 2015

\begin{tabular}{|l||c|c|c|c|c|c|c|c|c|c|c|c|}
\hline & $\mathbf{2 0 0 4}$ & $\mathbf{2 0 0 5}$ & $\mathbf{2 0 0 6}$ & $\mathbf{2 0 0 7}$ & $\mathbf{2 0 0 8}$ & $\mathbf{2 0 0 9}$ & $\mathbf{2 0 1 0}$ & $\mathbf{2 0 1 1}$ & $\mathbf{2 0 1 2}$ & $\mathbf{2 0 1 3}$ & $\mathbf{2 0 1 4}$ & $\mathbf{2 0 1 5}$ \\
\hline Total & 234.75 & 244.57 & 280.61 & 304.16 & 324.69 & 306.62 & 307.76 & 320.8 & 322.61 & 320.58 & 321.71 & 354.53 \\
\hline $\begin{array}{l}\text { Food and } \\
\text { non-alcoholic } \\
\text { beverages (\%) }\end{array}$ & 24.69 & 24.23 & 22.54 & 22.13 & 21.95 & 21.47 & 22.13 & 21.80 & 22.35 & 23.05 & 22.91 & 18.99 \\
\hline $\begin{array}{l}\text { Housing. water. } \\
\text { electicity. gas and } \\
\text { other fuels (\%) }\end{array}$ & 22.40 & 20.96 & 21.74 & 19.85 & 19.54 & 20.00 & 20.43 & 20.21 & 20.36 & 20.05 & 19.93 & 18.86 \\
\hline Transport (\%) & 6.97 & 8.21 & 7.89 & 8.58 & 7.78 & 7.66 & 7.21 & 7.96 & 8.12 & 7.83 & 7.64 & 11.06 \\
\hline
\end{tabular}

Source: Statistical Office of the SR, 2016 


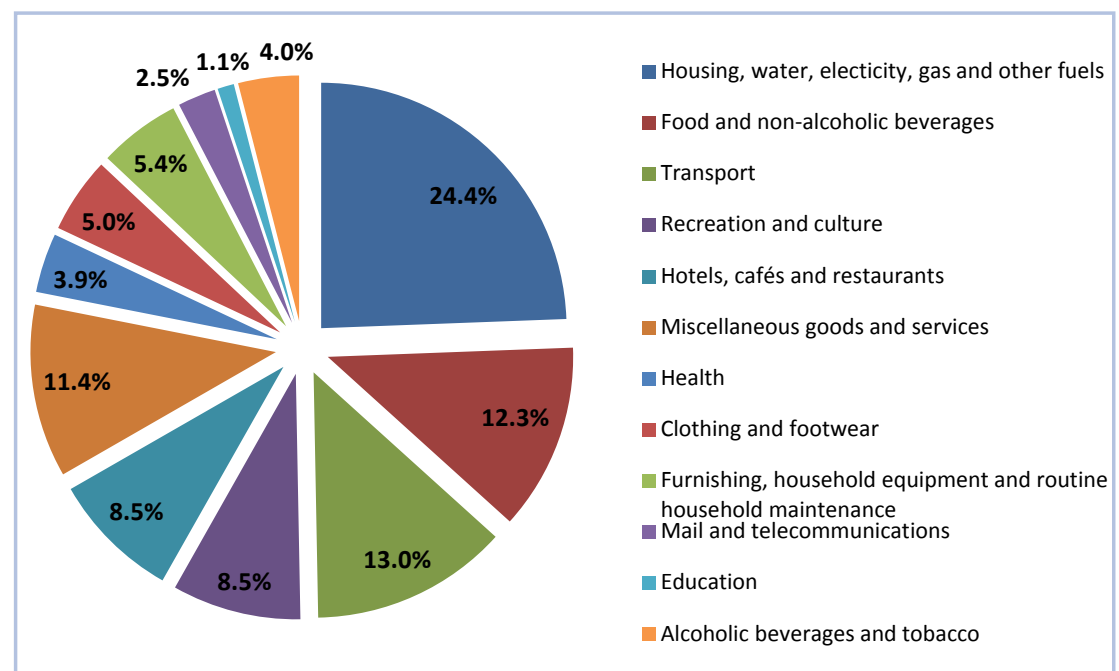

Figure 1 Structure of household expenditures in the EU-28 in 2015 in \% Source: own processing based on Eurostat, 2016a

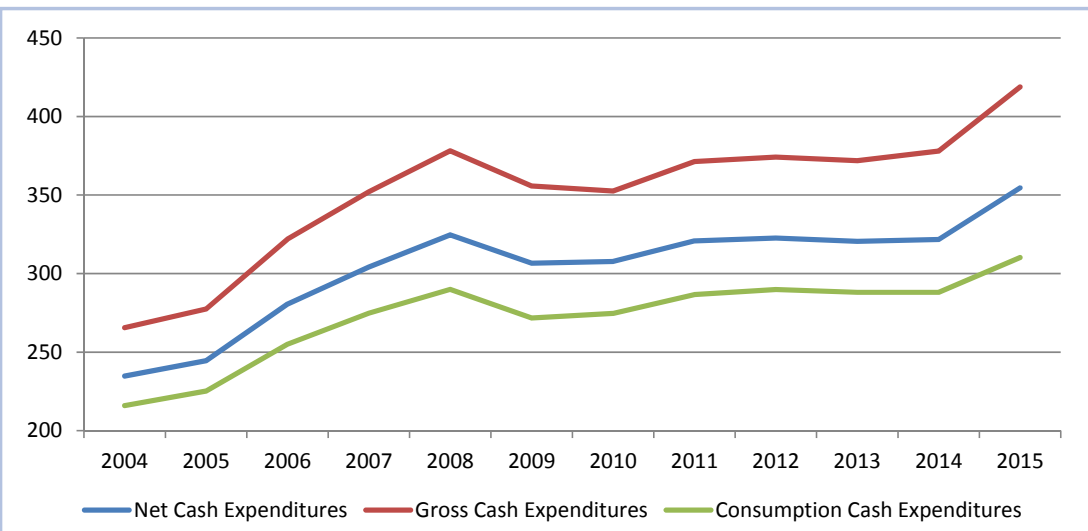

Figure 2 Development of gross, net and consumption cash expenditures between the years 2004 and 2015 in euros per month per one family member Source: Statistical Office of the SR, 2016

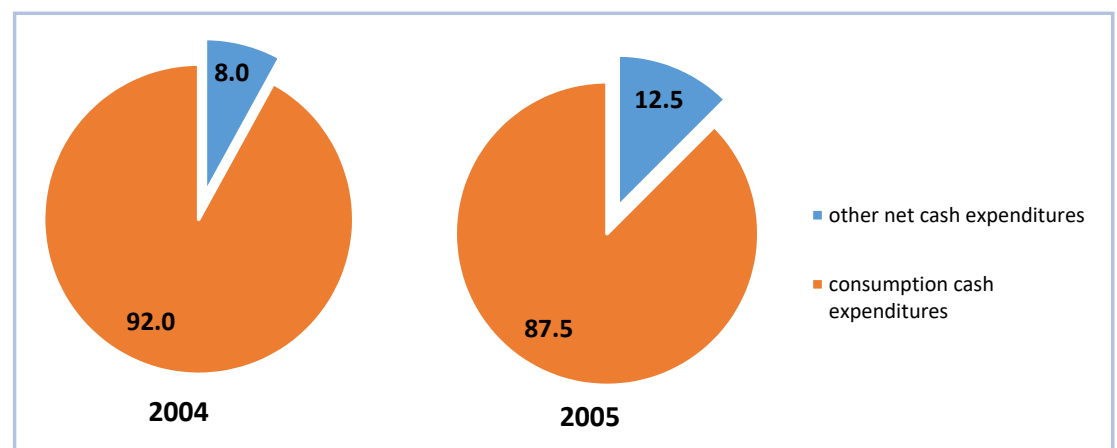

Figure 3 Comparison of the change in structure of net cash expenditures in 2004 and 2015 in \%

Source: Statistical Office of the SR, 2016

above-mentioned statement on the size of the share of basic expenditures on the total expenditures can also be applied on individual households. Dudek, Koszela and Landmesser (2012) found out that the share of basic expenditures on the total expenditures grows with a decline in household wealth.

The category of gross or net cash expenditures can be used to assess household expenditures.
Gross cash expenditures include consumption expenditures and other gross expenditures, i.e. other expenditures including income tax and compulsory contributions to the Social Insurance Agency and Health Insurance Companies. Net cash expenditures include consumption and other net expenditures, i.e. other expenditures excluding taxes and compulsory contributions to the Social Insurance Agency and Health Insurance Companies (Vojtková and Labudová, 2010). The term other expenditures refers to expenditures for various payments (property tax and other, other gross expenditures also income tax and compulsory personal insurance), cash donations outside the household, installment loans, purchase of shares and bonds, including short-term expenditures on private management (Statistical Office of the SR, 2017). The third group consists of consumption expenditures, which represent the amount of expenditures spent on goods and services. The difference in the development of gross, net and consumption cash expenditures is shown in Figure 2.

Gross, net and consumption expenditures of household have similar development (Figure 2). Over the years, similarly to the incomes, the gap between them increases. Whereas in 2004 the difference between net cash expenditures and gross cash expenditures was just under $€ 31$ (i.e. 11.6\%), in 2015 this difference was almost $€ 65$ (i.e. 15.35\%). The difference in consumption and net expenditures in 2004 was only $€ 19$ (8\%) and $€ 45$ (12.5\%) in 2015. In 2015, all of the aforementioned spending groups reached their maximum within the reference period. The second highest amount of expenditures was reached in 2008. In 2009, the gross cash expenditures dropped more than $€ 22$ compared to 2008 (i.e. 5.95\%). The other two spending groups recorded a decline of $5.6 \%$ in case of net cash expenditures and $6.3 \%$ in consumption expenditures. A further decline in expenditure amount was recorded in 2013 compared to 2012 with all groups decreasing by about $€ 2$ (i.e. $0.62 \%$ ).

When looking at the change in the development of net and consumption expenditures (Figure 2), it is also 

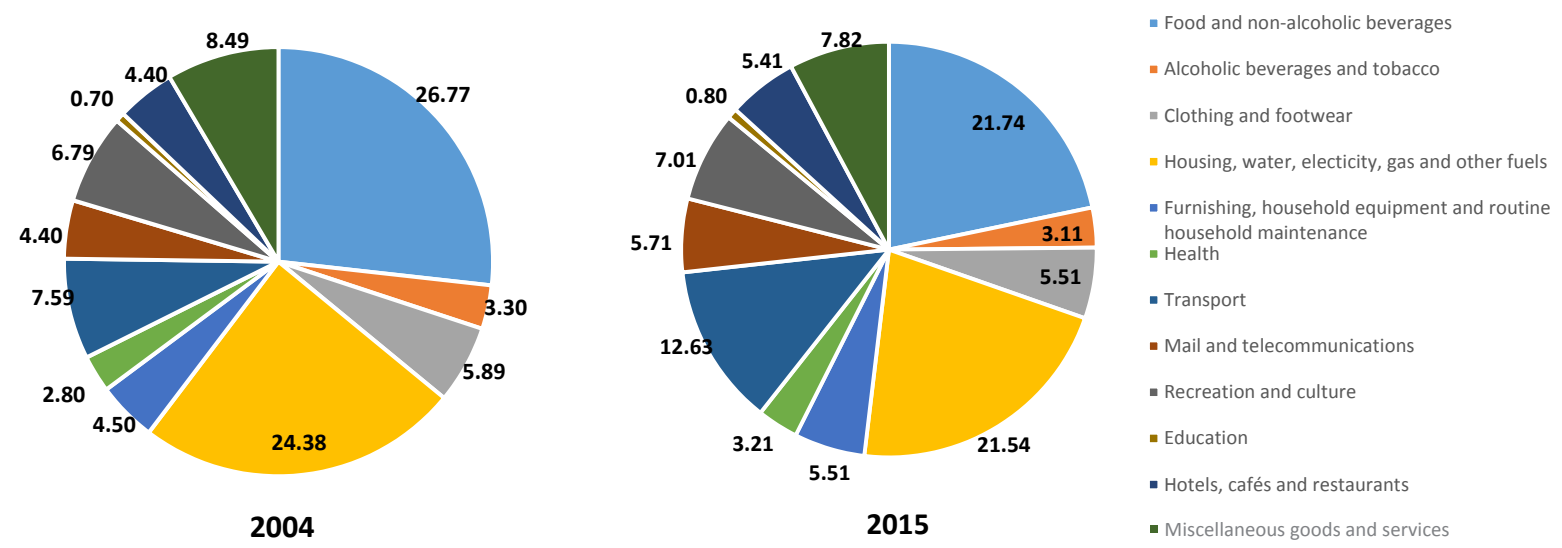

Figure 4 Comparison of the structure of household consumption expenditures in 2004 and 2015 in\% Source: Statistical Office of the SR, 2016

necessary to look at the structure of net cash expenditures (Figure 3).

Consumption expenditures of households in 2004 formed $92 \%$ of the net cash expenditures, while the remaining $8 \%$ was formed by the other net expenditures. In 2015, though, these other net expenditures increased by 4.5 percentage point at the expense of consumption expenditures.

Consumption expenditures, broken down by COICOP into 12 categories, have changed their structure over the reference period. The differences in categories of consumption expenditures in 2004 and 2005 can be seen in Figure 4 . Consumption expenditures spent on food and non-alcoholic beverages were by 5.1 percentage point (p.p.) lower in 2015 than in 2004, the decline in the consumption expenditures was recorded also in the category "housing, water, electricity, gas and other fuels" by 2.9 p.p., expenditures spent on clothing and footwear, as well as alcoholic beverages and tobacco decreased slightly. The largest increase in consumption expenditures in 2015 compared to 2004 was reported in the category "transport" (by 5 p.p.) and "mail and telecommunication" (by 1.3 p.p.). The smallest increase, however, occurred in case of consumption expenditures spent on education (only by 0.1 p.p.).
Differences in the structure of expenditures can be observed not only over time, but also in the individual regions of Slovakia. According to Želinský and Tartal'ová (2012), there are no significant differences in the basic structure of household consumption expenditures between the Slovak regions. The largest differences in percentage of total net cash expenditures between the regions of Slovakia were recorded in the categories "food and non-alcoholic beverages" (16.14-21.70\%), "housing" (16.76-21.46\%) and "recreation and culture" (4.76-7.08\%) (Statistical Office of the SR, 2016).

Table 2 Structure of expenditures of the total net cash expenditures in 2015 in \%

\begin{tabular}{|l|c|c|c|c|c|c|c|c|}
\hline Region & BA & TT & TN & NR & ZA & BB & PO & KE \\
\hline \hline Food and non-alcoholic beverages & 16.14 & 18.15 & 18.95 & 19.71 & 19.92 & 18.88 & 18.76 & 21.70 \\
\hline Alcoholic beverages and tobacco & 2.69 & 2.49 & 2.84 & 2.69 & 2.73 & 2.58 & 2.68 & 3.11 \\
\hline Clothing and footwear & 4.86 & 5.37 & 6.07 & 3.42 & 5.59 & 4.15 & 5.81 & 3.18 \\
\hline $\begin{array}{l}\text { Housing, water, electicity, gas and } \\
\text { other fuels }\end{array}$ & 18.97 & 18.02 & 16.76 & 19.81 & 17.10 & 20.32 & 18.39 & 21.46 \\
\hline $\begin{array}{l}\text { Furnishing, household equipment } \\
\text { and routine household maintenance }\end{array}$ & 4.93 & 4.46 & 5.80 & 4.83 & 4.52 & 5.02 & 4.66 & 4.54 \\
\hline Health & 2.73 & 2.33 & 3.03 & 2.97 & 3.01 & 2.51 & 3.43 & 2.66 \\
\hline Transport & 10.09 & 11.20 & 11.24 & 10.25 & 12.55 & 11.64 & 11.94 & 9.71 \\
\hline Mail and telecommunications & 5.34 & 4.61 & 4.64 & 5.13 & 4.68 & 4.89 & 5.07 & 5.27 \\
\hline Recreation and culture & 7.08 & 5.28 & 6.81 & 6.91 & 6.32 & 6.37 & 4.76 & 5.63 \\
\hline Education & 0.56 & 0.63 & 0.74 & 0.66 & 0.97 & 0.63 & 0.55 & 0.89 \\
\hline Hotels, cafés and restaurants & 5.12 & 4.11 & 5.09 & 4.25 & 5.52 & 4.04 & 5.08 & 4.20 \\
\hline Miscellaneous goods and services & 6.71 & 6.52 & 7.06 & 6.77 & 6.95 & 6.88 & 6.66 & 7.25 \\
\hline Other net cash expenditures & 14.77 & 16.82 & 10.97 & 12.59 & 10.14 & 12.10 & 12.21 & 10.40 \\
\hline
\end{tabular}

Source: Statistical Office of the SR, 26. 1. 2016 
The structure of expenditures in the individual regions generally confirmed the Engel's law cited above, stating that the higher the income, the lower the share of expenditures spent on essential living needs such as food, housing and transport. This is particularly confirmed by data on income and structure of expenditures from the Bratislava Region. However, while the lowest average equivalent household income was recorded in the Prešov Region, the share of expenditures spent on food and non-alcoholic beverages was lower than in majority of other regions of Slovakia. In the Bratislava Region, in 2015, only $16.14 \%$ of the total net cash expenditures was used for consumption of food and nonalcoholic beverages, while in the Košice Region, it was almost 22\%. Category "housing, water, electricity and other fuels" in 2015 accounted for $16.76 \%$ of the total net cash expenditure in the Trenčín Region and more than $20 \%$ of the total net cash expenditures in the Banská Bytrica and Košice Regions. However, "transport" in the Košice Region accounted for only $9.71 \%$ of the total net cash expenditures and in the Bratislava Region by only 0.39 percentage points more, while in the Žilina Region it was up to $12.55 \%$ (by 2.85 p.p. more than in the Košice Region). Consumption of alcoholic beverages and tobacco represents the largest share of the total net cash expenditures in the Košice Region (3.11\%).

\section{Dependencies Between the Different \\ Categories of Expenditures}

Identifying of the long-term balanced relationship between expenditure categories was preceded by the identification of dependence between them using a correlation matrix. In particular, we were interested whether there is a strong dependence between the three categories of expenditures, which represent the largest item in the budgets of Slovak households. Those are namely the following categories: expenditures on food and nonalcoholic beverages; housing, water, gas and electricity; and transport. The correlation matrix shows the results of the dependence force (Table 3).

According to the correlation matrix, there is a strong correlation between the category "food and non-alcoholic beverages" and the category "housing, water, electricity, gas and other fuels" (0.9346); however, only moderate dependence was found between the categories "food and non-alcoholic beverages" and "transport" (0.6104). Similarly, there was shown only moderate dependence (0.6668) in correlation between categories "households, water, electricity, gas and other fuels" and "transport". A strong correlation was found between category "healthcare" on the one side and categories "food and non-alcoholic beverages" (0.9640), "alcoholic beverages and tobacco" (0.9681), "housing, water, electricity, gas and other fuels" (0.9570), and "telecommunications" (0.9563) on the other side. Contrary, even negative correlation was seen between the category "education" on the one side and categories "hotels, cafés and restaurants" (-0.0212) or "clothing and footwear" $(-0.0372)$ on the other side. The category "education" has the strongest correlation with the category "miscellaneous goods and services" (0.82).

\section{Long-term Balanced Relationships}

Consequently, we were analysing the long-term balance relationships between the selected expenditure

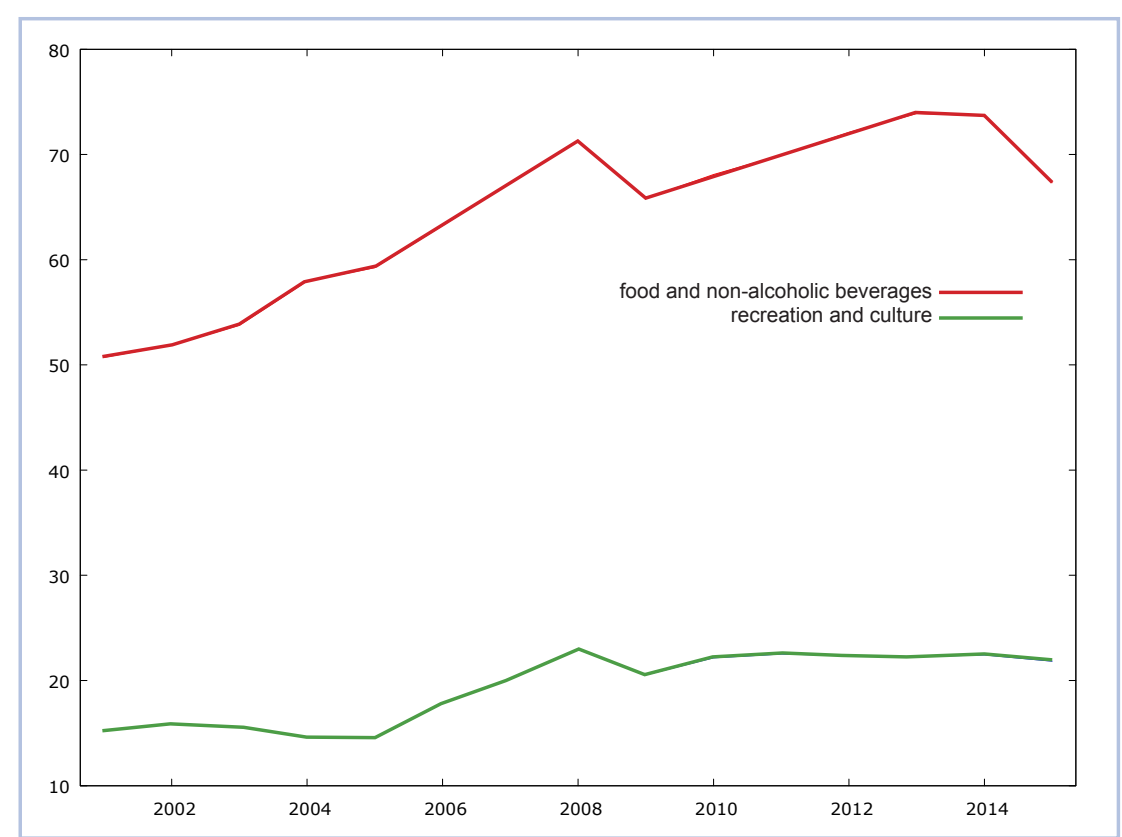

Figure 5 Evolution of the net cash expenditures for the categories "food and non-alcoholic beverages" and "recreation and culture" in euros per capita per month

Source: own processing in GRETL categories. Such relationship was manifested only in one case, between the categories "food and nonalcoholic beverages" and "recreation and culture".

Within the first step, we investigated the stationarity of both time series in a logarithmic shape using the unit root tests, namely the extended Dickey-Fuller test. Since both time series were non-stationary, we made their first differences, and tested the stationarity again (using the extended Dickey-Fuller test without a constant). The results of stationarity testing are documented in the Figure 6.

The aforementioned statements mean that in both cases we can reject the null hypotheses about the non-stationarity of the time series and confirm that time series for "food and non-alcoholic beverages" and "recreation and culture" are stationary since the $p$-value for the category "food and alcoholic beverages" equals to $0.03492 \quad(<0.05)$ and $p$-value for the category "recreation and culture" equals to $0.007303(<0.05)$.

In the second step, we performed the cointegrating regression of these two categories of expenditures using their logarithmic shapes (Figure 7).

This model reflects a long-term balanced relationship between 
Table 3 Correlation matrix of the structure of household expenditures

\begin{tabular}{|l|c|c|c|c|c|c|c|c|c|c|c|c|c|}
\hline & A & B & C & D & E & F & G & H & I & J & K & L & M \\
\hline \hline A & 1,000 & & & & & & & & & & & & \\
\hline B & 0,934 & 1,000 & & & & & & & & & & \\
\hline C & 0,423 & 0,391 & 1,000 & & & & & & & & & & \\
\hline D & 0,935 & 0,892 & 0,270 & 1,000 & & & & & & & & & \\
\hline E & 0,468 & 0,474 & 0,737 & 0,522 & 1,000 & & & & & & & & \\
\hline F & 0,964 & 0,968 & 0,316 & 0,957 & 0,472 & 1,000 & & & & & & & \\
\hline G & 0,610 & 0,706 & 0,515 & 0,667 & 0,831 & 0,688 & 1,000 & & & & & & \\
\hline H & 0,949 & 0,933 & 0,501 & 0,952 & 0,637 & 0,956 & 0,737 & 1,000 & & & & & \\
\hline I & 0,918 & 0,915 & 0,700 & 0,825 & 0,628 & 0,880 & 0,684 & 0,937 & 1,000 & & & & \\
\hline J & 0,145 & 0,124 & $-0,037$ & 0,352 & 0,584 & 0,219 & 0,622 & 0,255 & 0,031 & 1,000 & & & \\
\hline K & 0,855 & 0,871 & 0,691 & 0,731 & 0,556 & 0,819 & 0,688 & 0,869 & 0,952 & $-0,021$ & 1,000 & & \\
\hline L & 0,603 & 0,584 & 0,318 & 0,750 & 0,777 & 0,656 & 0,865 & 0,712 & 0,551 & 0,820 & 0,491 & 1,000 & \\
\hline M & 0,823 & 0,886 & 0,623 & 0,837 & 0,793 & 0,867 & 0,879 & 0,936 & 0,911 & 0,320 & 0,872 & 0,740 & 1,000 \\
\hline
\end{tabular}

Source: own processing of data
A - food and non-alcoholic beverages; B - alcoholic beverages and tobacco; C - clothing and footwear; D - housing, water, electicity, gas and other fuels; E - furnishing, household equipment and routine household maintenance; F - health; G - transport; $\mathrm{H}$ - mail and telecommunications; I - recreation and culture; $\mathrm{J}$ - education; $\mathrm{K}$ - hotels, cafés and restaurants; $\mathrm{L}$ - miscellaneous goods and services; $\mathrm{M}$ - other net cash expenditures

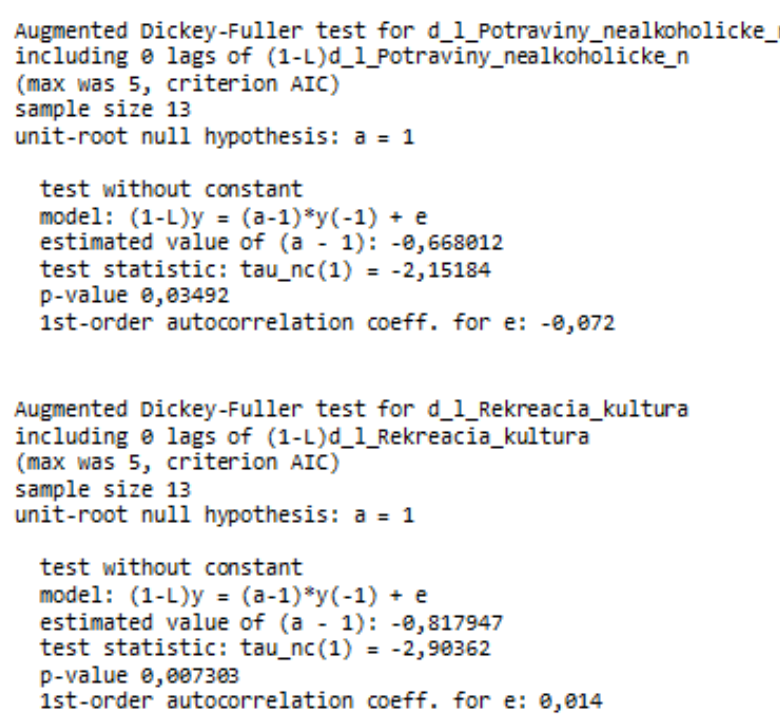

Figure 6 The results of the unit root tests for expenditure categories "food and non-alcoholic beverages" and "recreation and culture"

Source: own processing in GRETL

the two categories of expenditures, assuming that the stationarity test for residuals confirms the residual stationarity of this model. Again, we used a unit root test (the extended Dickey-Fuller test) to test the stationarity of the model's residuals (Figure 8).

Based on the asymptotic $\mathrm{p}$-value value $\left(2.146 \times 10^{-6}\right.$ $<0.05$ ) it can be concluded that the model residuals are stationary. Therefore, we can conclude a long-term balanced relationship between the two categories of expenditures defined by the cointegration regression

\begin{tabular}{|c|c|c|c|c|c|c|}
\hline \multicolumn{7}{|c|}{$\begin{array}{l}\text { Model: OLS, using observations } 2001-2015(\mathrm{~T}=15) \\
\text { Dependent variable: } 1 \text { _Potraviny_nealkoholicke_nap }\end{array}$} \\
\hline & Coefficient & & Error & t-ratio & $p$-value & \\
\hline const & 2,28009 & & 5371 & 9,2924 & $<0,0001$ & $* * *$ \\
\hline 1_Rekreacia_kultura & 0,636549 & & 30255 & 7,6669 & $<0,0001$ & **** \\
\hline Mean dependent var & \multirow{2}{*}{\multicolumn{2}{|c|}{4,158008}} & \multirow{2}{*}{\multicolumn{2}{|c|}{ S.D. dependent var }} & \multicolumn{2}{|c|}{0,127734} \\
\hline Sum squared resid & & & & & \multicolumn{2}{|c|}{0,056411} \\
\hline R-squared & \multicolumn{2}{|c|}{$\begin{array}{l}0,041369 \\
0,818895\end{array}$} & \multicolumn{2}{|c|}{$\begin{array}{l}\text { S.E. of regression } \\
\text { Adjusted R-squared }\end{array}$} & \multirow{2}{*}{\multicolumn{2}{|c|}{0,804964}} \\
\hline $\mathrm{F}(1,13)$ & \multicolumn{2}{|c|}{58,78150} & \multicolumn{2}{|c|}{$\begin{array}{l}\text { P-value (F) } \\
\text { Akaike criterion }\end{array}$} & & \\
\hline Log-likelihood & \multicolumn{2}{|c|}{22,91550} & \multicolumn{2}{|c|}{ Akaike criterion } & \multicolumn{2}{|c|}{$-41,83099$} \\
\hline Schwarz criterion & \multicolumn{2}{|c|}{$-40,41489$} & \multicolumn{2}{|c|}{ Hannan-Quinn } & \multicolumn{2}{|c|}{$-41,84608$} \\
\hline rho & \multicolumn{2}{|c|}{0,548046} & \multicolumn{2}{|c|}{ Durbin-Watson } & \multicolumn{2}{|c|}{0,727709} \\
\hline
\end{tabular}

Figure 7 Regression model for the expenditure categories "food and non-alcoholic beverages" and "recreation and culture"

Source: own processing in GRETL

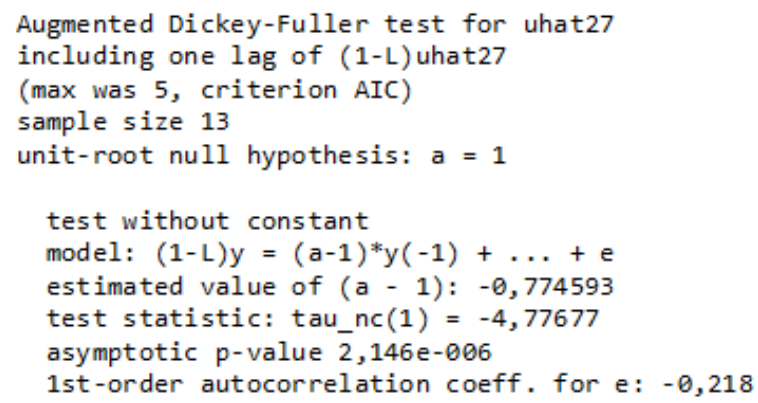

Figure 8 Stationarity test for the regression model residuals Source: own processing in GRETL 


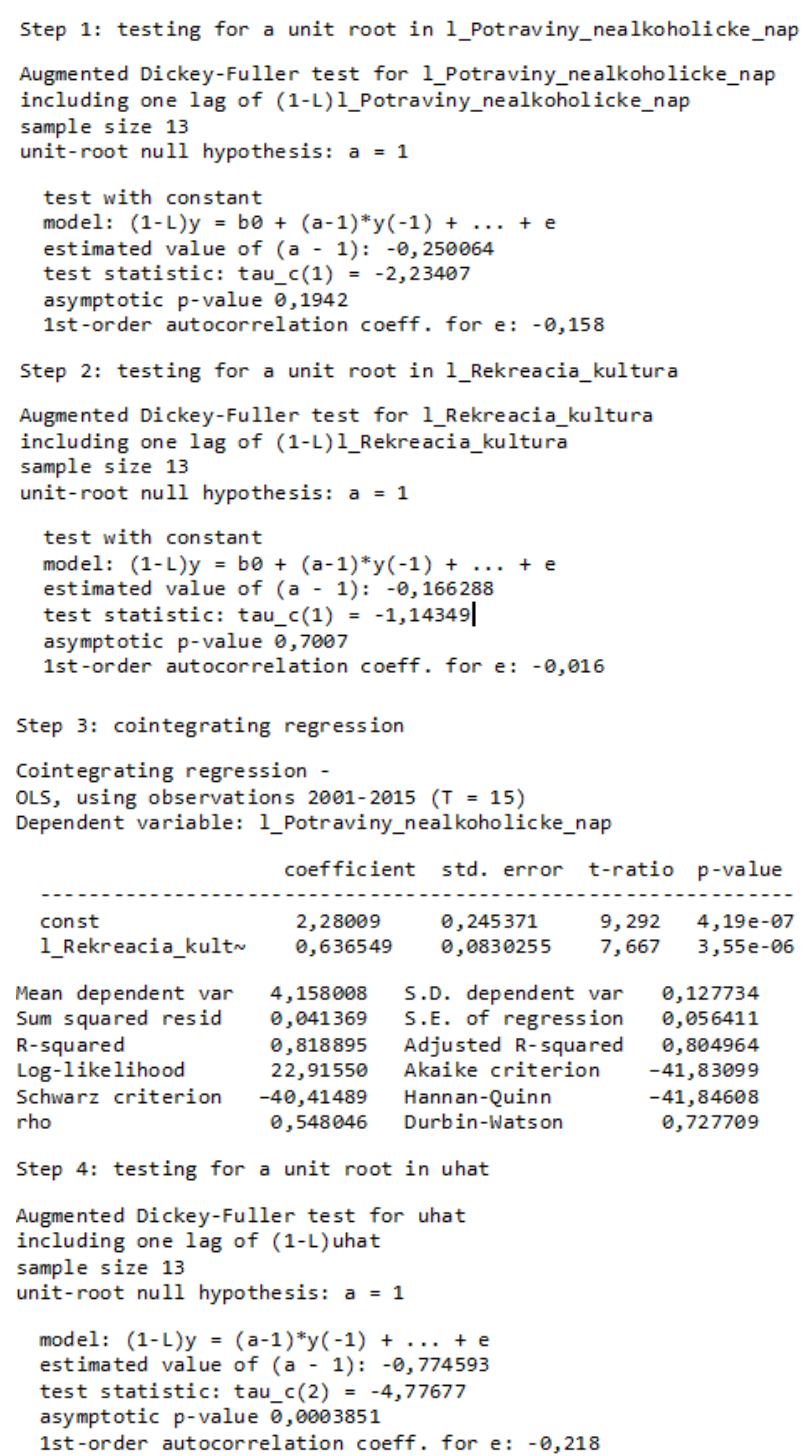

Figure 9 Engle-Granger test Source: own processing in GRETL

model: $y=2.28+0.64 x$, which shows that "food and nonalcoholic beverages" account for $64 \%$ of expenditures spent on recreation and culture. In other words, expenditures spent on food and non-alcoholic beverages are by $36.35 \%$ lower than expenditures on recreation and culture. The results were also confirmed by the Engle - Granger Cointegration Test (Figure 9).

Consequently, we tested short-term dynamics between these expenditure categories using a regression model designed from the first differences of the logarithmic shape of expenditure categories and from the correction member (residuals offset by two periods) to see how fast the balance between these categories was restored (Figure 10).

Based on the regression model, we can conclude that the model as such is statistically significant. Statistically significant is also the first difference of the logarithm shape of

\begin{tabular}{|c|c|c|c|c|c|}
\hline \multicolumn{6}{|c|}{$\begin{array}{l}\text { Model: OLS, using observations } 2003-2015(T=13) \\
\text { Dependent variable: d_1_Potraviny_nealkoholicke_n }\end{array}$} \\
\hline & Coefficient & Std. Error & t-ratio & $p$-value & \\
\hline const & 0,00460944 & 0,00852569 & 0,5407 & 0,6006 & \\
\hline d 1 Rekreacia kultura & 0,620681 & 0,119771 & 5,1822 & 0,0004 & $* * *$ \\
\hline uhat1_2 & $-0,730412$ & 0,184046 & $-3,9686$ & 0,0026 & $* * *$ \\
\hline Mean dependent var & 0,020029 & \multicolumn{2}{|c|}{ S.D. dependent var } & \multicolumn{2}{|c|}{0,051270} \\
\hline Sum squared resid & 0,008310 & \multicolumn{2}{|c|}{ S.E. of regression } & \multicolumn{2}{|c|}{0,028826} \\
\hline R-squared & \multirow{2}{*}{$\begin{array}{l}0,736566 \\
13,98011\end{array}$} & \multicolumn{2}{|c|}{ Adjusted R-squared } & \multicolumn{2}{|c|}{0,683880} \\
\hline $\mathrm{F}(2,10)$ & & \multirow{2}{*}{\multicolumn{2}{|c|}{$\begin{array}{l}\text { P-value }(F) \\
\text { Akaike criterion }\end{array}$}} & \multirow{2}{*}{\multicolumn{2}{|c|}{0,001269}} \\
\hline Log-likelihood & 29,36328 & & & & \\
\hline Schwarz criterion & $-51,03170$ & \multicolumn{2}{|c|}{ Hannan-Ouinn } & $-53,0$ & 492 \\
\hline rho & $-0,337465$ & \multicolumn{2}{|c|}{ Durbin-Watson } & \multicolumn{2}{|c|}{$\begin{array}{r}2,241250 \\
\end{array}$} \\
\hline
\end{tabular}

Figure 10 Regression model of the selected expenditure categories with a correction member Source: own processing in GRETL

the category "recreation and culture" what in the short term can be interpreted as follows: if expenditures on recreation and culture change by one percentage point, expenditures on food and non-alcoholic beverages will change by $0.62 \%$. The correction member $(-0.73)$ is statistically significant, which means that in case of disturbing the balance between the two expenditure categories, the balance can be corrected by $73 \%$ within two periods.

It can be, therefore, concluded that there is no longterm balanced relationship between COICOP expenditure categories, i.e., regression relationships between different categories of expenditures are false regressions. The only exceptions are expenditures spent on food and nonalcoholic beverages and expenditures spent on recreation and culture, where the long-term balanced relationship is characterized by cointegration regression. In this case, the expenditures on food and non-alcoholic beverages account for $64 \%$ of expenditures on recreation and culture.

\section{Conclusion}

Household income is one of the basic indicators of the living standards of the population. It affects the size and structure of household expenditures (Rozborilová, 2002) and allows statistical analysis of the living standard of the population (Vojtková and Labudová, 2010). Household income can be analysed through several categories of income. Equivalent disposable income is the most transparent one as it takes into account the size and structure of households.

Similarly to income, household expenditures can also be analysed through several categories. Gross, net as well as consumption expenditures of households showed similar development in the monitored period 2005-2015. All three groups reached their maximum in 2015 (net cash expenditures of $€ 354.53$ person $^{-1}$. month ${ }^{-1}$, gross cash expenditures of $€ 418.82$ person $^{-1}$. month $^{-1}$, consumption expenditures of households of $€ 310.21$ person $^{-1}$. month $^{-1}$ ).

Based on the Classification of Individual Consumption by Purpose (COICOP), the expenditures are divided into 12 categories. Consumption expenditures spent on food and non-alcoholic beverages decreased by 5.1 p.p. in the monitored period, similarly a decrease was recorded in case of expenditures spent on housing, water, electricity, gas and fuels (by 2.9 p.p.). Expenditures used on clothing and footwear, as well as expenditures on alcoholic beverages and tobacco decreased only slightly. On the contrary, in 
the monitored period, the largest increase in consumption expenditures was recorded in the category "transport" (by 5 p.p.) and the category "mail and telecommunication" (by 1.3 p.p.). The lowest increase was found in case of expenditures spent on education (by only 0.1 p.p.).

There is no long-term balanced relationship between the COICOP expenditure categories. The only exceptions are expenditures spent on food and non-alcoholic beverages and on recreation and culture, where the long-term balanced relationship is characterized by the cointegration regression, according to which the expenditures on food and nonalcoholic beverages account for $64 \%$ of expenditures spent on recreation and culture. In the event of balance disturbing between the two categories, $73 \%$ of this imbalance will be corrected in two periods.

\section{References}

DICKEY, A. D. - FULLER, A. W. 1979. Distribution of the Estimators for Autoregressive Times Series With a Unit Root. In Journal of the American Statistical Association, vol. 74, 1979, no. 366, pp. 427-431. ISSN 0162-1459.

DUDEK, H. - KOSZELA, G. - LANDMESSER, J. 2012. Wpływ sytuacji dochodowej na strukturę wydatków gospodarstw domowych. In Ekonomika i Organizacja gospodarki żywnościowej, Warszawa: SGGW, 2012, pp. 237-247. ISSN 2081-6979.

DUDEK, H. - KOSZELA, G. 2013. Comparison of households'expenditures structures in selected countries of European Union. In Acta Scientarium Polonorum Oeconomia, vol 12, 2013, no. 3, pp. 5-15 ISSN 1644-0757.

EUROSTAT. 2016. Eurostat Yearbook. Luxembourg: Eurostat, 2016. ISSN 2443-8219 [online]. [cit.2017-01-19]. Available at: <http://ec.europa.eu/eurostat/statistics-explained/index.php/ Europe_in_figures_-_Eurostat_yearbook>

FRENDÁKOVÁ, A. 2010. Vývoj sklonu k úsporám slovenských domácností v čase hospodárskej recesie. In National and regional economics VIII. Košice: TUKE, pp. 287-295 ISBN 978-80-553-0517-2 [online]. [cit. 2017-01-19]. Available at: <http://www3.ekf.tuke.sk/ konfera2010/zbornik/files/konfera2010_zbornik.pdf>

KAŠČÁKOVÁ, A. - NEDELOVÁ, G. 2008. Regionálne rozdiely hospodárenia domácností na základe štatistiky rodinných účtov. In Forum Statisticum Slovacum, vol. 4, 2008, no. 5, pp. 67-72. ISSN 1336-7420.
KOLLÁROVÁ, V. - VLADOVÁ, A. 2009. Štruktúra súkromnej spotreby na Slovensku a porovnanie s európskymi krajinami. In Biatec, vol. 17, 2009, no. 8, pp. 25-28. ISSN 1335-0900.

LISÝ, J. et al. 2011. Ekonómia. Bratislava : Iura edition, 2011, 631 p. ISBN 978-80-8078-406-5.

MEYER, D. B. - SULLIVAN, J. X. 2003. Measuring the Well-Being of the Poor Using Income and Consumption. In The Joint IRP/ ERS Conference on Income Volatility and Implications for Food Assistance, May 2-3, 2002 in Washington, DC. [online]. [cit. 201701-20]. Available at: <http://www.nber.org/papers/w9760>

PAUHOFOVÁ, I. - PÁLENÍK, M. 2012. Súvislosti starnutia európskej populácie vo väzbe na formovanie domáceho dopytu. In Pauhofová, I. - Zelinský, T. 2012. Nerovnost’ a chudoba v Európskej únii a na Slovensku. Košice : Technická univerzita, pp. 33-38. ISBN 9788055312255.

ROZBORILOVÁ, D. 2002. Teória spotreby a úspor investícií a vládnych výdavkov. Bratislava : lura edition, 2002, 238 p. ISBN 80-89047-32-7. ŠEVELA, M. 2004. Convergence of household expenditures of the EU-member and acceding countries in the years 1995-2002. In Agricultural economics, vol. 50, 2004, no. 7, pp. 301-307. ISSN 0139-570X.

ŠTATISTICKÝ ÚRAD SR. 2016. Štatistická ročenka Slovenskej republiky 2016. Bratislava: Štatistický úrad SR. [online]. [cit. 201701-19]. Available at: <http://www.statistics.sk>

ŠTATISTICKÝ ÚRAD SR. 2017. Metodické vysvetlivky. [online]. [cit. 2017-01-19]. Available at: <http://www.statistics.sk/pls/elisw/ objekt.sendName?name=metodika_S16>

TARTAL'OVÁ, A. - ŽELINSKÝ,T. 2012. Rozdelenie príjmov na Slovensku: Analýza citlivosti rozdelenia príjmov na vol'bu ekvivalentnej škály. In Pauhofová, I. - Zelinský, T. 2012. Nerovnost’ a chudoba v Európskej únii a na Slovensku. Košice : Technická univerzita, 2012, pp. 99-106. ISBN 9788055312255.

VIDOVÁ, J. 2015. Domácnosti a ich bohatstvo v Slovenskej republike. In Finančné trhy, vol. 7, 2015, no. 1, pp. 1-15. ISSN 13365711 [online]. [cit. 2017-01-19]. Available at: <http://www.derivat. sk/index.php?PagelD=2396>

VOJTKOVÁ, M. - LABUDOVÁ, V. 2010. Regionálna analýza výdavkov a príjmov domácností v Slovenskej republike. In Ekonomický časopis, vol. 58, 2010, no. 8, pp. 802-820. ISSN 0013-3035. 